Turkish Journal of Unmanned Aerial Vehicles

Türkiye İnsansız Hava Araçları Dergisi

https://dergipark.org.tr/tr/pub/tiha

e-ISSN 2687-6094

\title{
Türk Hukuk Mevzuatında Sivil İnsansız Hava Araçları Hukukunun Güncel Durumu
}

\author{
Şafak FiDAN ${ }^{*} 10$, Ali ULVí2 ${ }^{\circledR 0}$
}

${ }_{1}^{1}$ Mersin Üniversitesi, Teknik Bilimler Meslek Yüksekokulu, Mimarlık ve Şehir Planlama Bölümü, Mersin, Türkiye

${ }^{2}$ Mersin Üniversitesi, Fen Bilimleri Enstitüsü, Uzaktan Algılama ve Coğrafi Bilgi Sistemleri Anabilimdal,, Mersin, Türkiye

\author{
Anahtar Kelimeler \\ İHA \\ Uzaktan Algılama \\ Fotogrametri \\ Hukuk \\ İHA Hukuku
}

\section{ÖZ}

İnsansız hava araçları, uzaktan kontrol edilen ve belirlenen bir uçuş rotasında insansız uçuş gerçekleştirerek, bu uçuşla istenilen faaliyetleri yerine getiren araçlardır. Günümüzde insansız hava araçları birçok dalın ortak kullandığı bir multidisipliner araç konumundadır. Askeri alanda bașlayan sivil alanda da yaygın olarak kullanılan insansız hava araçlarının kullanım alanları teknolojinin gelişimine paralel olarak hızla artmaktadır. $\mathrm{Bu}$ gelişmelerin öngörüsü ile zamanla uygulamalarının artacağı değerlendirilmektedir. Bu artışın yasal sorunları büyüterek sektörün önüne getireceği unutulmamalıdır. Bu konu güvenlik ve insan yaşamının gizliliği boyutunun olduğu düşünüldüğünde daha da önemli hale gelmektedir. Sivil alandaki kullanım alanlarının artmış olması ve alt başlıklarda daha da çeşitleneceği düşünülürse hukuksal çerçevesinin belirlenmesi ve gelişmelere göre düzenlenmesinin önemini arttırmaktadır. Bu çalışmada sivil insansız hava araçlarının Türk hukuk mevzuatı açısından durumu incelenmiştir. Yapılan çalışmada İnsansız hava araçlarının mevzuatı sadece kullanıcılar açısından değerlendirilmiş olup mevzuatın öngördüğü İHA' larla ilgili teknik detaylara yer verilmemiştir.

\section{Current Status of Civil Unmanned Aerial Vehicles Law in Turkish Legal Legislation}

\author{
Keywords \\ UAV \\ Remote Sensing \\ Photogrammetry \\ Law \\ UAV Law
}

\begin{abstract}
Unmanned aerial vehicles are vehicles that perform unmanned flight on a remotely controlled flight route and perform the desired activities with this flight. Today, unmanned aerial vehicles are a multidisciplinary vehicle used by many branches. The usage areas of unmanned aerial vehicles, which are widely used in the civilian field, which started in the military field, are increasing rapidly in parallel with the development of technology. With the foresight of these developments, it is evaluated that their applications will increase over time. It should not be forgotten that this increase will increase the legal problems and bring them to the sector. This issue becomes even more important when it is considered that there are dimensions of security and privacy of human life. Considering that the areas of use in the civilian area have increased and that they will be more diversified in sub-headings, it increases the importance of determining the legal framework and arranging it according to the developments. In this study, the situation of civil unmanned aerial vehicles in terms of Turkish legal legislation is examined. In the study, the legislation of unmanned aerial vehicles was evaluated only in terms of users, and technical details about the UAVs stipulated by the legislation were not included.
\end{abstract}




\section{GíRIş}

İnsansız hava araçları, uzaktan kontrol edilen ve belirlenen bir uçuş rotasında insansız uçuş gerçekleștirerek, bu uçuşla istenilen faaliyetleri yerine getiren araçlardır (Çoban \& Oktay, 2017; Kahveci \& Can, 2017).

$\mathrm{Bu}$ faaliyet alanları günümüzde teknolojinin gelișimine paralel olarak hızla artmaktadır. Bu gelişme gelecek zaman dilimlerinde de sivil ve askeri çalışmalarda önemli bir yer alacağını göstermektedir. Günümüzde insansız hava araçları birçok dalın ortak kullandığı bir multidisipliner araç konumundadır. Bu durumun oluşması nedeni yapılan işte zamanı kısaltması, maliyeti azaltması ve her geçen gün hassasiyetlerinin artmasıdır. Teknolojideki gelişmeler İnsansız Hava Araçlarının (IHA) kullanım alanlarını çeşitlendirmektedir (Korumaz vd., 2011; Yakar vd., 2016; Kaya \& Yiğit, 2020). Bu araçların farklı koşullarda, bölgelerde ve performansta uçabilme yetenekleri onlara değişik kullanım alanlarının da önünü açmaktadır.

İnsansız hava araçları sivil ve askeri kullanım olarak sinıflandırılır (Yakar vd., 2005; Yakar, 2015). Askeri amaçlı kullanıma yönelik olanları kendi içerisinde silahsız ve silahlı olmak üzere ikiye ayrılmaktadır. Silahsız insansız hava araçları askeri amaçlı gözetleme, istihbarat, hedef tespiti vb. alanlarda, silahlı insansız hava araçları ise belirlenen hedeflerin imhasında birer taarruz unsuru olarak kullanılmaktadırlar (Yakar \& Yılmaz, 2008; Ocak \& Gürbüz, 2018).

Sivil kullanıma yönelik olanları harita üretimi, arkeoloji, medya, ormancılık, tarım, doğa gözlemleri, afet, denizcilik, lojistik, sağlık, hayvancllık, meteoroloji, inşaat, kamu güvenliği vb. etkinliklerde kullanılmaktadırlar (Yakar vd., 2016; Ulvi vd., 2019). İnsansız hava araçlarının sivil kullanım alanları teknolojinin gelişmesine ve insanoğlunun hayal gücüne koşut artacağı da görülmektedir.

$\mathrm{Bu}$ sınıflandırmadaki sivil alanın yoğunluğu ve alt başlıklarda daha da çeşitleneceği düşünülürse hukuksal çerçevesinin belirlenmesi ve gelişmelere göre düzenlenmesinin önemini arttırmaktadır (Yakar vd., 2009; Yiğit \& Uysal, 2020; Ulvi vd., 2020). Bu çalışmada sivil insansız hava araçlarının ulusal hukuk mevzuatı açısından durumu incelenmiştir. Yapılan çalışmada insansız hava araçlarının hukuksal yapısında hukuk sistemimiz açısından yeterli mevzuatın olduğu teknolojik ve yönetsel düzenlemelere göre güncel revizyonlara yer verildiği görülmektedir.

Alışveriș merkezlerinde, teknoloji mağazalarında ve hatta oyuncak mağazalarında İHA satışı yapıldığı görülmektedir. Bu alanın mevzuat kapsamındaki kısmına da çok uyulmadığı gözlemlenmektedir.

Ayrıca bu çalışmada mevzuat sadece kullanıcılar açısından değerlendirilmiş olup mevzuatın öngördüğü İHA'larla ilgili teknik detaylara yer verilmemiştir.

\section{INSSANSIZ HAVA ARAÇLARININ HUKUKI BOYUTU}

Sivil ve askeri insansız hava aracı sınıflandırması hukukunun da belirlenmesinde önemli bir etken olmaktadır (Yardımcl, 2019a; 2019b; Kaya vd., 219; Şenol vd., 2020). Askeri amaçlı insansız hava araçlarının kullanımı ve hukuki boyutu çalışmanın kapsamı dıșında tutulmuştur. Şekil 1'de bu çalışmalarda kullanılan sivil insansız hava araçlarına örnekler görülmektedir.
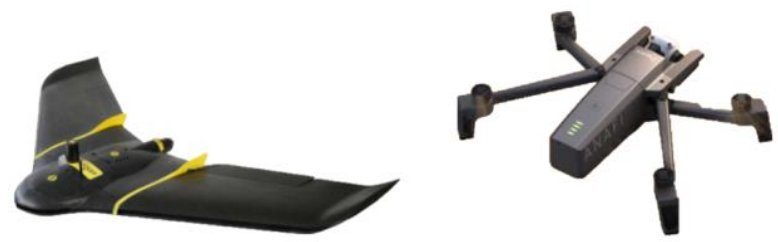

Şekil 1.1. Sivil insansız hava araçları örnekleri (Topcon eBee plus ve parrot anafi) (URL-1, 2021)

Dünya üzerinde insansız hava araçları ile çalışılan ülkelerde çeşitli düzeylerde insansız hava araçları, bunlarla toplanan veriler ile toplanma şekli ile ilgili yasal düzenlemeler yapılmaktadır.

\subsection{Ulusal İnsansız Hava Araçları Hukuku}

Türk hukuk mevzuatının temel ilkelerini ve hukuki dayanağını Türkiye Cumhuriyeti Anayasası oluşturmaktadır. Anayasaya uygun olarak çıkartılan birçok Cumhurbaşkanlığı Kararnamesi, Kanun, yönetmelik, genelge, talimat ve tebliğ mevzuatımızın yapısını oluşturmaktadır. Bu akış Şekil 2'de görülmektedir.

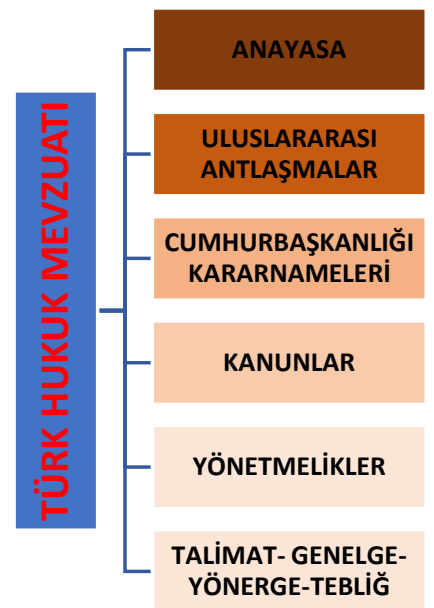

Şekil 2. Türk hukuk mevzuatı

Türkiye Cumhuriyeti Anayasası'nda konu ilgili dolaysız bir hüküm bulunmamaktadır. Ancak insansız hava araçlarının oluşturabileceği, özel hayatın gizliliği, konut dokunulmazlığı, haberleşme hürriyeti ile kişi hak ve hürriyetlerini koruma maddeleri ile kişi yaşamını güvence altına almaktadır.

Uluslararası sivil havacılık antlaşması ile sivil havacılık geçici sözleşmesi hakkında kanunun 8 . 
Maddesi pilotsuz uçabilen araçların yani insansız hava araçlarının izin verilmesi durumunda başka ülkelerin hava sahalarını kullanabileceği ve antlașma devletlerinin de sivil hava sahalarında pilotsuz uçabilen uçakları tehlike oluşturmayacak şekilde denetim altında bulundurması gerektiği ifade edilmektedir. Sözleşme hava seyrüseferi, Uluslararası Sivil Havacılık Teşkilatı, uluslararası hava nakliyatı, son hükümler adlı beș kısım ve eklerden oluşmaktadır (URL-2, 2021).

Cumhurbașkanlığı hükümet sistemine geçilmesinden sonra çıarılan 4 numaralı Cumhurbașkanlığı kararnamesine göre Sivil Havacılık Genel Müdürlüğü görev, yetki ve sorumlulukları düzenlenerek, SHGM' nün Ulaştırma ve Altyapı Bakanlığına bağlı olarak çalışmalarını sürdüreceği ifade edilmektedir. Kararnamenin SHGM' nün görev ve yetkilerini düzenleyen 437. Maddenin i, j, k ve ö fıkralarında, özetle sivil hava araçlarının tescil ve sicil işlemlerinin uluslararası standartta yerine getirmek, bunları uluslararası kuruluşlarla paylaşmak ve bu kayıtları tutmak, emniyetli uçuşlar için gerekli önlem ve denetim yaparak, belgeler ile ilgili her türlü işlemleri yapmak ve kayıtları tutmak, aykırı hareket edenlerle ilgili gerekli yasal işlemleri yapmak, sektörün gelișmesi için gerekli tedbirleri almak ve önerilerde bulunmayı ve diğer maddelerinde de bu hususları desteklemektedir (URL-3, 2021).

Türk Sivil Havacılık kanunu, hava aracını, havalanabilen ve havada gidip gelebilen araç olarak tanımlamaktadır. Anılan yasa Türk hava sahasından yararlanacak hava vasıtaları kısmında, Türk hava sahasında uçabilecek vasitalar olarak, sicile kayıtlı Türk sivil hava vasıtaları ile asıl ve tüzelkișilerin ticari emelle, fiyat karșılığında hava tașıtlarıyla ticari ve diğer faaliyetlerde bulunmaları için ilgili bakanlıktan izin almalarından bahsetmektedir. Türk Sivil havacılık kanunu, Türk hava hâkimiyeti kararları, sivil hava kazaları, ticari hava firmaları, havaalanları ve kuruluşlar, hava vasıtaları ve sicillerin tutulması, hava vasıtalarına ait uçuş ilkeleri, sivil havacılık personeli vb. kısımlardan oluşmaktadır (URL-4, 2021).

\subsection{1. İnsansız Hava Sistemleri Talimatı}

Türk Sivil Havacılık kanunu ve 4 sayılı Cumhurbașkanlığı Kararnamesinin 31. Bölümüne dayanılarak İnsansız Hava Sistemleri Talimatı (SHTİHA) hazırlanmış ve 2021 yılında revizyon 4 ile İHA kurs programlarının MEB kurs programı onayı şartı ile yeniden gözden geçirilmiştir.

İnsansız Hava Sistemleri Talimatı (SHT-İHA)revizyon 4 insansız hava araçları ile amaç, kapsam, dayanak ve tanımlar, sınıflandırma, ithal teknik uygunluk, zorunlu teçhizat, uçuşa elverişlilik ve özel uçuş izni, bakım ve onarım, sorumluluk, sigorta, kayıt, tescil, uçuş operasyon el kitabı ve pilot lisansları, uçuş izni, uçuşa yasak bölgeler ve uçuş şartları, son hükümler başlıklarını içeren beş bölüm ile başvuru ve kontrol formları listesi, İHA güvenlik taahhütnamesi, İHA pilot adaylarına yönelik eğitimler, risk analizi değerlendirme hususları, İHA eğitim kuruluşu taahhüt beyanı, İHA 0 ve İHA 1 ticari eğitimi vermek isteyen kuruluşlardan istenecek belgeler, hafif İHA işleticisi sertifikası talep dosyası, İHA 2 ve İHA 3 sınıflarında eğitim vermek isteyen üreticilerin sağlaması gereken şartlar ve İHA başvuru akış şeması olmak üzere dokuz ekten oluşmaktadır.

$\mathrm{Bu}$ talimat, sivil İnsansız Hava Aracı (İHA) sistemlerinin dış alımı, satışı, kayıt ve tescili, uçuşa elverişliliğin sağlanması, pilotların niteliklerini, hava trafik hizmetleri ve İHA operasyonlarına ilişkin usul ve esasları belirlemek amacıyla hazırlanmıştır (Yiğit \& Ulvi, 2020; URL-5, 2021).

Talimat, sivil insansız hava araçlarının, ilgili sistemleri, bunları ithal edecek, satışını yapacak, işletecek ya da kullanacak gerçek ve tüzel kişileri, bu kapsamda görev alacak personeli, İHA ekibini ve hava sahası kullanımı ile verilecek hava trafik hizmetlerini kapsamaktadır (Kaya vd., 2021; URL-5, 2021).

İnsansız Hava Sistemleri Talimatı (SHT-İHA) kapsamı dışında kalan İHA' lar Şekil 3'te görülmektedir.

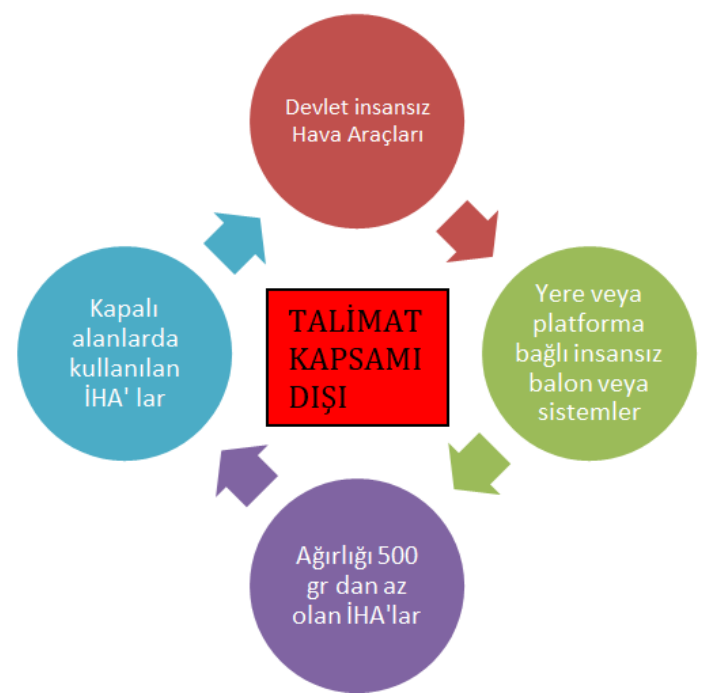

Şekil 3. İnsansız Hava Sistemleri Talimatı (SHT-İHA) kapsamı dışında kalan İHA'lar.

Bu talimatın tanımlar ve kısaltmalar bölümü 4 . Maddesinde; Algıla ve sakın, ayrılmış hava sahası, devlet insansız hava aracı, faydalı yük operatörü, görsel görüş hattı (VLOS), görüş hattı dışı(BLOS), İHA işleticisi, İHA pilotu, İHA ekibi, İHA gözlemcisi, insansız hava aracı (İHA), insansız hava aracı sistemi (İHAS), izne tabi bölge, kontrol bağl, kontrol istasyonu, NOTAM, otonom operasyon, özel izne tabi bölge, serbest bölge, uçuş planı ve uçuşa yasak bölge tanımları yapılmıștır.

Talimattaki kısaltmalar ve bunların anlamları Tablo 1' de gösterilmektedir. 
Tablo 1. Kisaltmalar ve anlamları (URL-5, 2021)

\begin{tabular}{cc}
\hline KISALTMA & ANLAMI \\
\hline ADS-B & Otomatik Bağımlı Gözetim Yayını \\
AGL & Yer Yüzeyinden Yükseklik \\
AIP & Havacılık Bilgi Yayını \\
AMM & Hava aracı Bakım El Kitabı \\
ATC & Hava Trafik Kontrolü \\
CTR & Kontrol Bölgesi \\
EASA & Avrupa Havacılık Emniyeti Ajansı \\
& Avrupa Seyrüsefer Hava Emniyeti \\
EUROCONTROL & Teşkilatı Entegre Uçuş Plan İşleme \\
IFPS & Sistemi \\
& Uluslararası Sivil Havacılık \\
ICAO & Organizasyonu \\
IFR & Aletli Uçuş Kuralları \\
IMC & Aletli Uçuş Meteoroloji Şartları \\
IR & Aletli Uçuşa Yetkili \\
PPL & Hususi Pilot Lisansı \\
TCAS & Trafik Uyarı ve Çarpışma Önleme \\
& Sistemi \\
\hline
\end{tabular}

\section{Sinıflandırma}

Sınıflandırma işlemi İHA azami kalkış ağırlıkları dikkate alınarak yapılmaktadır. Buna göre azami kalkış ağırlı̆̆ı olarak 500 gr ve 500 gr dahil olmak üzere $4 \mathrm{~kg}$ kadar İHA 0, $4 \mathrm{~kg}$ ile $4 \mathrm{~kg}$ dahil olmak üzere $25 \mathrm{~kg}$ kadar İHA $1,25 \mathrm{~kg}$ ve $25 \mathrm{~kg}$ dahil olmak üzere $150 \mathrm{~kg}$ kadar İHA 2, $150 \mathrm{~kg}$ ve $150 \mathrm{~kg}$ dahil olmak üzere daha fazla ağırlığa sahip olanlar İHA 3 olacak şekilde yapılan sınıflandırma Şekil 4'te görülmektedir.

Tablo 2. IHHA'ların sınıflandırılması (URL-5, 2021).

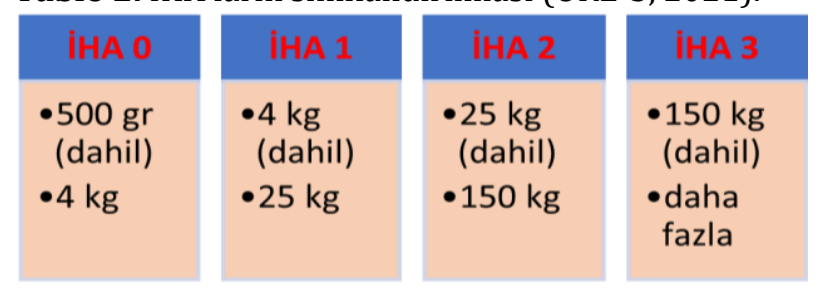

\section{Zorunlu teçhizat}

İHA 0 sınıfı insansız hava araçlarının zorunlu teçhizat ile donatılmış olması işletmecisinin, sahibinin ve pilotunun seçimine bağlı olmasına rağmen İHA 1, İHA 2 ve İHA 3 sinıf İHA'lar ekipmanlarla ve sistem bileșenleri ile donatılmış olmalıdır (URL-5, 2021).

\section{Uçuşa elverişlilik ve özel uçuş izni belgesi}

IHA 0 sınıfındaki İHA için tahditli tip Sertifikası, uçuşa elverişlilik sertifikası veya özel uçuş izni belgesi düzenlenmez. İHA1 sınıfındaki İHA için bu evrakların yerine emniyet ve uygunluk beyanları kabul edilmektedir. İHA 2 sinıfındaki İHA için, İHA1 sınıfı için uygulanan kurallar ile birlikte 3 yıl süreli özel uçuş izni belgesi düzenlenir. İHA 3 sınıfındaki İHA için uçuşa elverişlilik sertifikası düzenlenir ve her 3 yılda bir yenilenir. Ticari amaçla uçurulmak istenen İHA'lardan İHA 0 ve İHA 1 sinıfinda olanlar en az İHA 2 sınıfında istenen belgeleri sağlamak zorundadır ve İHA0 ve İHA1 sınıfı İHA'lara özel uçuş izin belgesi düzenlenir (URL-5, 2021).

\section{Bakım ve onarım gereklilikleri}

İHA ve sistemlerinin bakım ve onarımlarının, üreticilerin yayımladığı el kitaplarına göre yapılmasından İHA pilotu sorumludur (URL-5, 2021).

\section{Sorumluluk ve Sigorta}

Tüm İHA ve sistemlerinin işleticileri ve sahipleri üçüncü şahıslara verecekleri zararlardan sorumludur. $25 \mathrm{~kg}$ üstü İHA ile ağırlığına bakılmaksızın ticari faaliyet gerçekleştiren İHA için, Mali Mesuliyet Sigortası Yönetmeliğine göre sigorta yaptırılır ve sigortasız uçuş yapılmaz (URL-5, 2021).

\section{Kayıt işlemleri ve tescil işlemleri}

İHA Başvuru işlemleri, ithalatçı ve üretici kayıt işlemleri, pilot kayıt işlemleri, İHA kayıt ve tescil işlemleri, uçuş izni işlemleri, özel uçuş izni ve uçuş koşulları onayı (ticari faaliyetlerde), uçulacak bölge için uçuş İzninden oluşmaktadır.

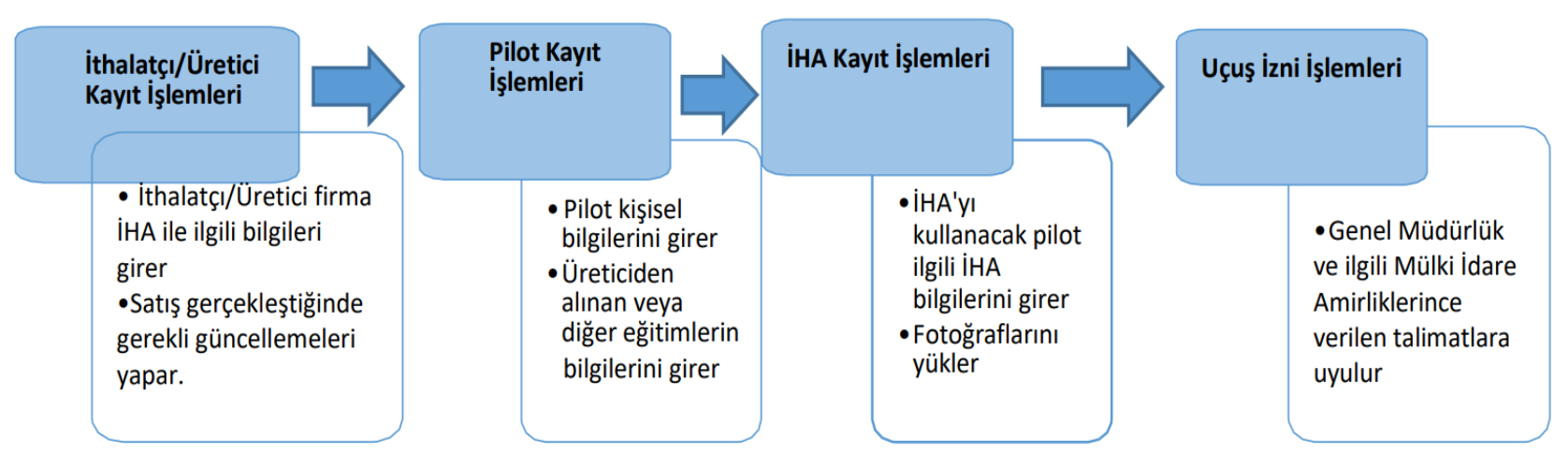

Şekil 4. Ticari olmayan faaliyet ve/veya İHA0/IHA1 hava araçları için başvuru iş akışı (URL-5, 2021). 
İHA 0 ve İHA 1 kategorisindeki hava araçlarının kayıtları Genel Müdürlük tarafından elektronik ortamda oluşturulan kayıt sistemi üzerinden yapılır. Ülkemizde üretimi yapılan her bir İHA, üreticisi tarafından aynı gün içerisinde kayıt sistemine kaydedilir. İthalatçı firma tarafından satılan her bir İHA' nın bilgileri satın alan kişi bilgileriyle birlikte, satan firmanın sorumlu yöneticileri tarafından aynı gün içerisinde kayıt sistemine kaydedilir. Yurtdıșından bireysel olarak getirilen veya yurt içinde devir alınan İHA, en geç 3 gün içerisinde kayıt sistemine kaydedilir.

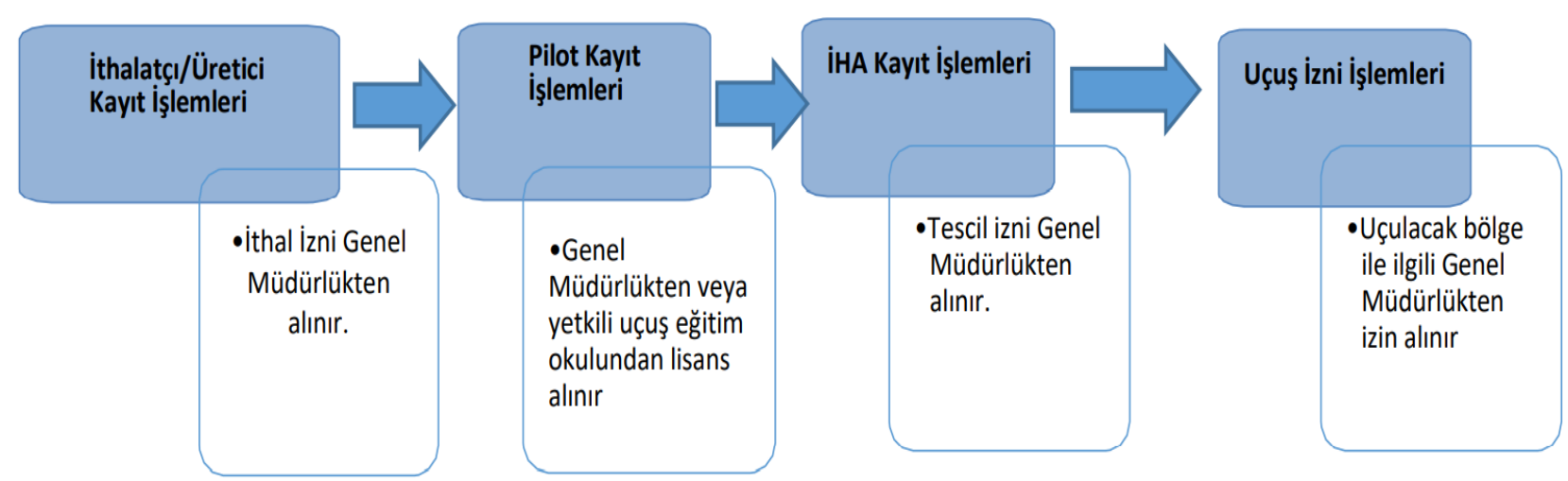

Şekil 5. Ticari faaliyet ve/veya İHA2/İHA3 hava araçları için başvuru iş akışı (URL-5, 2021).

İHA0 ve İHA1 sınıfındaki İHA'lar için tescil işlemi yapılmaz. Türk Uçak Siciline ilk defa kaydedilecek, sahip ve işletici değişikliği yapılacak İHA2 ve İHA3 sınıfındaki İHA'ların tescil işlemlerinde tescil müracaat formu, terkin başvurusundan bulunulacaklara terkin müracaat formu düzenlenir.

\section{Pilot lisansı sınıflandırması ve gereklilikleri}

Tüm sınıflarda İHA pilot lisansı düzenlenecek kişilerden adli sicil belgesi istenir. İHA 0 ve İHA 1 uçuracak kişiler için Genel Müdürlükçe herhangi bir lisans düzenlenmez. Ancak söz konusu kişiler oluşturulan internet tabanlı Kayıt Sistemi'ne T.C. Kimlik Numarası, İsim-Soyisim ve ikametgâh bilgileri, Telefon, e-posta, vb İletişim bilgileri, 18 yaşından küçükler için ileride doğabilecek hukuki ve cezai sorumlulukları kabul ettiklerine dair kanuni mümessillerince noterde tanzim ve tasdik edilmiş taahhütname belgelerle kayıt olmak zorundadırlar. İHA0 sınıfı pilotlar en az 12 yaşında ve İHA1 sınıfı pilotlar en az 15 yaşında olmalıdır. İHA 0 ve İHA 1 kategorisindeki hava araçları ile hobi veya sportif amaçlı uçuş yapacaklar için eğitim zorunluluğu bulunmamaktadır. İHA0 ve İHA1 kategorisindeki hava araçlarını ticari amaçla kullanacak pilotlar için gerekli dersler alınmalıdır. $\mathrm{Bu}$ eğitimleri tamamlayanlara yetkili eğitim kuruluşu tarafından İnsansız Hava Aracı Ticari Pilot Sertifikası düzenlenir ve bu sertifika İHA pilot kayıt başvurusunda Genel Müdürlüğe gönderilir. İHA 0 ve İHA 1 kategorisindeki hava araçlarını ticari amaçla kullanacak pilotlar, İHA sisteminin üreticisi, yetkili temsilcisi, üniversiteler, teknolojik araştırma geliştirme çalışması yapan merkezler veya Genel Müdürlük tarafindan yetkilendirilmiş Onaylı Eğitim Organizasyonları tarafından verilen eğitimleri alır. Ticari amaçlı eğitim vermek için uygun görülen kuruluşların listesi Genel Müdürlügün resmi internet sitesinde yayınlanır. İHA
0 ve İHA 1 kategorisinde ticari olarak eğitim verecek olan üretici, yetkili temsilci, üniversite ve AR-GE merkezleri taahhütname ve gerekli belgeler ile Genel Müdürlüğe müracaat eder. Tüm sinıflardaki İHA eğitim kuruluşları Milli Eğitim Bakanlığından özel İHA pilotu yetiştirme kursu açma izni almak zorundadırlar. Yükseköğretim Kanunu uyarınca kurulmuş yükseköğretim kurumları Milli Eğitim Bakanlığından kurs açma izni gerekliliğinden muaftır. 18 yaşın altındaki İHA pilotlarının üçüncü şahıslara verdikleri zararlardan hukuki ve cezai sorumluluk kanuni mümessiline aittir. Ticari nitelikli uçuş yapacak İHA0 ve İHA1 kategori pilotlardan yukarıda belirtilenlere ek olarak B sınıfı sürücü olur sağlık raporu gereksinimlerini karşılayan sağlık raporu istenir (URL-5, 2021).

İHA2 sinıfındaki İHA'yı kullanacak İHA 2 sınıfı pilot için Genel Müdürlük tarafından 3 yıl süreli İHA 2 Pilot Lisansı düzenlenir. Bu lisans için;

- Onaylı Eğitim Organizasyonları veya Ek-9'da belirtilen gereklilikleri sağlayan İHA2 üreticisi kuruluşlar tarafından düzenlenen teorik bilgi eğitimlerine katılarak başarıyla tamamlamış olmak,

- İHA ve sistemlerinin üreticisinden veya yetkili temsilcisinden en az 36 saat uçuş eğitimi ve en az 3 saat bakım onarım eğitimi alarak her birini başarıyla tamamlamak,

- $\mathrm{R} / \mathrm{T}$ telsizle haberleşme kursunu başarıyla tamamlamak,

- Genel Müdürlük veya EASA üyesi bir ülke tarafından düzenlenen ve geçerli olan asgari 2 nci Sınıf Sağlık Sertifikası sahibi olmak,

- $\quad$ En az 18 yaşında olmak (URL-5, 2021). 
İHA 3 sınıfındaki İHA'yı kullanacak İHA 3 sınıfı pilot için Genel Müdürlük tarafından 3 yıl süreli İHA 3 Pilot Lisansı düzenlenir. Bu lisans için;

- Genel Müdürlük veya EASA üyesi bir ülke tarafından düzenlenen ve geçerli olan asgari 2 nci Sınıf Sağlık Sertifikası sahibi olmak.

- En az 18 yaşında olmak.

- Onaylı Eğitim Organizasyonları veya İHA3 üreticisi kuruluşlar tarafından düzenlenen teorik bilgi eğitimlerine katılarak başarıyla tamamlamış olmak,

- İHA ve sistemlerinin üreticisinden veya yetkili temsilcisinden en az 54 saat uçuş eğitimi ve en az 3 saat bakım onarım eğitimi alarak her birini başarıyla tamamlamak.

- $\mathrm{R} / \mathrm{T}$ telsizle haberleşme kursunu başarıyla tamamlamak (URL-5, 2021).

Pilota teorik eğitim verecek eğitici sayısı en az 2 olup aşağıda belirtilen nitelikleri sağlar.

- En az ön lisans diplomasına sahip olmak.

- Eğiticinin eğitimini başarıyla tamamlamak veya doktorasinı tamamlamış akademik personel olmak ya da pedagojik formasyon eğitimi almış olmak (URL-5, 2021).

\section{IHA pilotu sorumlulukları}

İHA pilotu, uçuşun güvenli yürütülmesinden ve uçuşla ilgili idari, mali ve teknik kuralların yerine getirilmesinden sorumludur. IHA pilotu, faydalı yüklerin yasal çerçevede kullanılmasından sorumludur. İHA pilotu, uçuşla ilgili her türlü sorumluluğu kabul ettiğine dair imzaladıkları taahhüttü, uçuş izni başvurusu dosyasına ekler. İHA 2 ve İHA 3 sınıfı pilotlar lisanslarının geçerlilik süresinin sona erdiği tarih ile 12 ay öncesi arasındaki sürede en az 12 saat uçuş ve en az 12 adet iniş kalkış yaptıklarını kanıtlayıcı belgeler ile Genel Müdürlüğe başvuru yaptıklarında lisans süreleri 3 yıl süreyle uzatılır. Lisans sahibi yukarıdaki uçuş saatine ve iniş kalkış sayılarına lisans geçerlilik tarihinin son bir yılı içerisinde ulaşamaz ise İHA ve sistemlerinin üreticisinden veya yetkili temsilcisinden bir saat uçuş eğitimi alarak Genel Müdürlüğe bașvuru yaptıklarında lisans süreleri uzatılır. İHA 2 ve İHA 3 sınıfı pilotlar, lisanslarının geçerlilik süresinin sona erdiği tarih itibariyle 5 yll içerisinde lisans yenilemelerini yaptırmadıkları takdirde lisansları yenilenmez. $\mathrm{Bu}$ durumda ilk defa lisans düzenlenirken sorumlu oldukları tüm eğitimleri, ilgili Maddede belirtilen gerçek/tüzel kuruluşlardan \%50 oranında kısaltılmış şekilde tekrar almaları gerekir (URL-5, 2021).

\section{Uçuş izni gereklilikleri}

Ticari faaliyetler dışında sportif ve amatör amaçla gerçekleştirilecek uçuşlarda, belirtilen kurallara uyulmak kaydı ile, serbest (yeşil) bölgelerde Genel Müdürlükten uçuş izni Kayıt sistemi tarafından otomatik verilir. Bu sınıflar için mahallin en büyük mülki idare amiri tarafından yasaklanan yer ve zamanlarda uçuş yapmak yasaktır. Özel izne tabi (kırmızı) bölgelerde yapılacak her türlü uçuşlarda ise 10 iş günü öncesinden gerekçesi ile birlikte Genel Müdürlük resmi internet sayfasında yer alan İHA Uçuş İzni Talep Formu ile başvuru yapılır. İzne tabi bölgelerde, yapılacak her türlü uçuşlarda ise 5 iş günü öncesinden Genel Müdürlük tarafından oluşturulan resmi internet sayfası üzerinden başvuru yapılır. İzne tabi bölgelerde Genel Müdürlükçe oluşturulan web tabanlı sistem üzerinden 400 feet altında yapılacak uçuşlar için yapılan başvurular ilgili mülki idare amirlikleri tarafından incelenir ve uygun görülmesi halinde söz konusu talebe ilişkin NOTAM yayınlanır. İlgili sivil/askeri kurumlar ve Genel Müdürlük tarafından lüzumu halinde söz konusu izin iptal edilebilir. Uçuş izni alınması halinde; işletici/pilot/şahıs tarafından Türkiye AIP' sinde yer alan hükümlere ve belirtilen diğer kurallara uyulması zorunludur. İHA ile uçuşların gerçekleștirilebilmesi amacıyla tesis edilen serbest (yeşil) bölgeler Türkiye AIP'si ENR 5.5 bölümünde ilan edilir. Söz konusu sahaların güncelliği her yıl Genel Müdürlükçe kontrol edilir. İzne tabi bölgelerde 400 feet üzerinde yapılacak her türlü uçuşta en az 10 iş günü öncesinden gerekçesi ile Genel Müdürlük resmi internet sayfasında yer alan İHA Uçuş İzni Talep Formu ile bașvuru yapılır (URL-5, 2021).

İHA2 ve İHA3 sınıfı İHA'lar için; Tüm sahalarda gerçekleştirilecek İHA uçuşunda gerekli koordinasyonun yapılabilmesi için 10 iş günü öncesinden Genel Müdürlüğe İHA Uçuş İzni Talep Formu ile başvuru yapılır. Başvurulara ilişkin ilgili sivil ve askeri kurumlardan olumlu görüș alınmasını müteakip söz konusu sahaların NOTAM ile tüm hava sahası kullanıcılarına duyurulması sağlanır. Söz konusu taleplere ilişkin ilgili kurumlardan olumsuz görüş alınması veya Genel Müdürlük tarafından uygun görülmemesi halinde uçuş izni verilmez. İHA işletmecisi veya sahibi, başvurunun onaylanmasını takiben uçuşların düzenleneceği NOTAM' lanmış hava sahasından sorumlu ATC ünitesi ile acil durumlar haricinde operasyondan en az bir gün önce uçușa ilişkin usuller üzerinde mutabakat sağlar. Bu müsaadeler, İHA operasyonları için geçerli olan Standart Harekât Usullerine dayalı olacaktır. Standart Harekât Usulleri; normal usulleri, planlanmamış durumlara ilişkin usulleri, hava aracının acil durumdan kurtarılmasına diğer bir deyişle uçuşun sona erdirilmesine ilişkin usulleri içerecektir. Başvuru dosyası, uçuşun düzenleneceği ayrılmış hava sahasının koordinatlarını, bu sahada icra edilecek uçuşun saatlerini, ayrılmış hava sahasında kullanılacak uçuş seviyesini, acil durum usullerini, İHA ve sistemlerinde kullanılacak frekanslar gibi ilgili 
bilgileri içerir. Genel Müdürlük ilgili diğer kurumlarla koordinasyon sonucunda uygun bulunması halinde uçuş müsaadesi ve NOTAM yayınlar. Uçuş izni alınması halinde; ișletici/pilot/Hafif İHA ișleticisi tarafından Türkiye AIP' sinde yer alan hükümlere ve belirtilen diğer kurallara uyulması zorunludur. Özel izne tabi (kırmızı) bölgelerde uçuş yapılması talepleri, gerekçeleri ile birlikte 10 iş günü öncesinden Genel Müdürlüğe Uçuş İzni Talep Formu ile iletilir (URL-5, 2021).

$500 \mathrm{gr}$ altı İHA'lar için hava aracı ve pilot kayıt zorunluluğu olmamakla birlikte, yapılacak ticari uçuşların uçuş emniyeti ile can ve mal güvenliğine etkisine ilişkin değerlendirmelerin yapılabilmesi teminen İHA uçuşunun gerçekleştirileceği sahanın ilgili kurumlarla koordinasyonun yapılabilmesi için 10 iş günü öncesinden Genel Müdürlüğe İHA Uçuş İzni Talep Formu ile başvuru yapılır. 500 gr altı İHA'larla sportif ve amatör amaçlı gerçekleştirilecek uçuşlar için serbest bölgeler (yeşil) kullanılmalıdır (URL-5, 2021).

\section{Özel izne tabi bölgeler}

Özel izne tabi (kırmızı) bölge olarak tanımlanan ve yer alan sahalarda risk analizi yapılmadan ve Genel Müdürlükten izin alınmadan herhangi bir sınıftaki İHA ile uçuş yapılması yasaktır:

- İrtifaya bağlı olmaksızın havalimanlarında, en yakında bulunan pistin kenarından $5 \mathrm{NM}$ (9 km) mesafeden daha yakın sahada,

- İrtifaya bağlı olmaksızın seyrüsefer yardımcı cihazları, heliport, heliped, hava parkı, Genel Müdürlük resmi internet sitesinde yayınlanmış olan denize/iniș kalkıș alanları, vb. merkez olmak üzere $5 \mathrm{NM}\left(\begin{array}{lll}9 & \mathrm{~km}\end{array}\right)$ yarıçaplı sahada,

- $400 \mathrm{ft}$ üzerinde yapılacak uçuşlarda,

- Türkiye AIP'si ENR 5.1 bölümünde yer alan "Yasak, Tahditli ve Tehlikeli Sahalar"da,

- Askeri binalar ve tesisler, cezaevi, akaryakit depoları ve istasyonları, silah/fișek fabrika ve depoları gibi kritik yapı, tesis ve varlıkların çevresinde;

- $\quad$ NOTAM ile ilan edilen sahalarda,

Arama, kurtarma ve afet gibi öngörülemeyen acil durumlarda, Genel Müdürlük ile gerekli koordinasyonun sağlanması kaydıyla istisnai olarak Uçuş İzni verilebilir (URL-5, 2021).

\section{Uçuş şartları ve alan gereklilikleri}

İHA0 ve İHA1 sınıfındaki İHA'lar ile serbest (yeşil) bölgelerde gerçekleştirilecek uçuşlarda mahallin en büyük mülki idare amiri tarafından yasaklanmayan yer ve zamanlarda uçulması durumunda;

- Sadece görerek meteorolojik koșulların sağlandığı durumlarda, gündoğumugünbatımı saatleri arasında ve en az $2 \mathrm{~km}$ görüşe açık havalarda uçuş gerçekleştirilebilir,

- İHA, yatayda 500 metreyi geçmeyecek şekilde pilotun görüş alanında olmalıdır,

- Yerden (AGL) 400 feet (120 metre) yüksekliğin üzerine çıkılmamalıdır, ç) İnsan ve yapılardan en az 50 metre uzaklıkta uçuş gerçekleştirilmelidir.

İHA2 ve İHA3 sınıfındaki İHA'lar;

- Hava trafik usulleri açısından VFR uçuş gerçekleştirilen hava aracı statüsünde kabul edilmesi sebebiyle, uluslararası kurallar ve Türkiye AIP'sinde yer alan hükümler ve olabilecek diğer düzenlemeler dâhilinde uçuş gerçekleştirebilirler,

- Uygun ekipmanlara sahip ve gerekli izinleri alınmış İHA'lar ile yapılan uçuşlar hariç tutulmak üzere, gece VFR uçuş gerçekleştiremez.

İHA uçuşları için havaalanı, heliport ya da hava parkı gerekliliği yoktur. Bununla birlikte, sportif ve bireysel amaçlı uçuşlarda hava parkı ve / veya belirlenmiş alanların kullanımı tercih edilmelidir. İHA0 ve İHA1 sınıfındaki İHA'lar için sportif/amatör ve bireysel amaçlı uçuşlarda serbest (yeşil) bölgeler dışında uçuş yapılamaz (URL-5, 2021).

\section{Ayırma sağlama ve çarpışma önleme}

Uçuşlar esnasında, diğer hava araçları ile ayırmayı sağlamak ve çarpışmayı önlemek İHA pilotunun sorumluluğundadır (URL-5, 2021).

\section{Minimum ayırma minimaları}

İHA kendisi için ayrımlanan ve NOTAM'lanan alan dışında uçuş gerçekleştirilemez. Kendine ayrılmış alanlarda uçuș, diğer hava araçları ve mânialarla ayrılması sorumluluğu İHA pilotuna aittir (URL-5, 2021). 


\section{Acil durum usulleri}

Hava araçlarının acil durum usulleri İHA'lar içinde geçerlidir. İnsanların ve diğer hava sahası kullanıcılarının emniyetini sağlamak için, ATC ile koordine edilerek emniyet gereklilikleri arttırılır. İHA sistemin uçuş yaptığı sorumluluk alanının büyüklüğüne göre yeterli sayıda mecburi iniş ve düşürme bölgelerini belirlemeleri gerekir. (URL-5, 2021).

\section{Kontrol linki kaybı}

Kontrol kaybında sistem kabiliyetlerini, tasarlanmış kurtarma alanlarına göre otomatik olarak dönüşü belirleyerek uçuşu bitirmek gerekir. $\mathrm{Bu}$ planlamanın yapılaşmıș alanlar üzerinde planlamamak gerekir. Önceden belirlenmiş kurtarma alanına otomatik geçiş ve ardından uçuş sona erdirme sisteminin aktif hale getirilmesi gereklidir. Kontrol linkinin kopması durumunda, sorumlu İHA pilotu acil durum bildirir. İHA üzerinde transponder sistemi olması durumunda, A7700 transponder kodu otomatik olarak devreye girer. Kontrol linki kaybı nedeniyle acil durum görüntüsünü otomatik olarak uygulayan İHA, acil durum yaşayan hava aracı işlemi görür (URL-5, 2021).

\section{Güvenlik}

İHA işleticisi ve pilotu, İHA' nın herhangi bir yasadışı eyleme karşı aracının dışarıdan müdahalelere karşı güvenliğini sağlamakla yükümlüdür. İHA sahibi ve pilotu güvenlik taahhütnamesindeki tedbirleri almakla yükümlüdür (URL-5, 2021).

\section{Sorumluluklar, güvenlik ve yasaklar}

İHA sahipleri, İHA ve sistemlerinin kategorisine göre üretici ya da Genel Müdürlük tarafından belirlenen şartlarda muhafaza edilmesinden, İHA ve sistemlerin uçuş emniyetini tehlikeye düşüren olaylarını, en geç 48 saat içerisinde Genel Müdürlüğe rapor etmekten, Genel Müdürlük tarafından onaylanmayan değişikliklerin sistemde yapılması veya bu Talimattaki hükümlere aykırı iş ve işlemler yapılması durumlarında, Genel Müdürlük tarafından yayınlanan sertifikalar, izinler ve verilen haklar sona erer. Genel Müdürlük sertifikaların, izinlerin ve beyanların geçerlilik şartlarının korunduğunu doğrulamak için rastgele denetimler yapma hakkını saklı tutar. İHA sahibi ve pilotu özel hayatın gizliliği ve mahremiyeti konusuna özen gösterir. Aksi halde Türk Ceza Kanunu'nun ilgili Maddeleri kapsamındaki hükümler uygulanır (URL-5, 2021).

\section{SONUÇLAR}

Dünya üzerinde hukuk sistemlerinde insansız hava araçları ile ilgili mevzuatı bulunmayan ülkeler mevcuttur. Türk hukuk mevzuatında İnsansız Hava araçları güncel durumu yeterlilik göstermektedir. Mevzuatımızda kalkış ağırlığına göre yapılan sınıflandırmanın, kayıt, belgeleme, yeterlilikler, bakım vb. düzenlenmiștir. Teknolojideki gelişmelerin insansız hava araçlarını getireceği yere göre yeni düzenlemeler ise kaçınılmazdır.

Ancak sivil kullanımda sınıflandırmanın dışında alışveriş merkezlerinde, teknoloji mağazalarında ve hatta oyuncak mağazalarında İHA satışı yapıldığı görülmektedir. Bu alt düzey kullanımlarında mevzuat çerçevesinde ancak talimat dışında düzenlenmesi gerekir.

\section{KAYNAKÇA}

Çoban S \& Oktay T (2017). İnsansız Hava Araçlarının Hukuki Ve Etik Boyutu, 17.18/11/2017 4. Ulusal Havacılık Teknolojisi ve Uygulamaları Kongresi, 71-80.

Kahveci M \& Can N (2017). İnsansız Hava Araçları: Tarihçesi, Tanımı, Dünya'da ve Türkiye'deki Yasal Durumu, Selçuk Üniversitesi, Mühendislik Fakültesi, Bilim ve Teknik Dergi, C5, S4, 511535,ISSN:2147-9364,Konya.

Kaya Y \& Yiğit A. (2020). Dijital El Kameraları Kullanılarak Kültürel Mirasın Belgelenmesi. Türkiye Fotogrametri Dergisi, 2 (2), 33-38.

Kaya Y, Şenol H İ, Memduhoğlu A, Akça Ş, Ulukavak M \& Polat N (2019). Hacim Hesaplarında İHA Kullanımı: Osmanbey Kampüsü Örneği. Türkiye Fotogrametri Dergisi, 1(1), 7-10.

Kaya Y, Yiğit A Y, Ulvi A \& Yakar M (2021). Arkeolojik Alanların Dokümantasyonununda Fotogrametrik Tekniklerinin Doğruluklarının Karşılaştırmalı Analizi: Konya Yunuslar Örneği. Harita Dergisi, 165, 57-72.

Korumaz A G, Dülgerler O N \& Yakar M (2011). Kültürel Mirasın Belgelenmesinde Dijital Yaklaşımlar, S.Ü. Müh.-Mim. Fak. Derg., c.26, s.3, 2011.

Ocak D G \& Gürbüz N (2018). Türkiye'de Sivil İHA Kullanımı Hakkında Güncel Düzenlemeler, Artıcletter, Summer 2018, 71-94.

Şenol H İ, Memduhoglu A \& Ulukavak M (2020). Multi instrumental documentation and 3D modelling of an archaeological site: a case study in Kizilkoyun Necropolis Area. Dicle Üniversitesi Mühendislik Fakültesi Mühendislik Dergisi, 11(3), 1241-1250.

Ulvi A, Yakar M, Yiğit A Y \& Kaya Y (2019). The Use of Photogrammetric Techniques in Documenting Cultural Heritage: The Example of Aksaray Selime 
Sultan Tomb, Universal Journal of Engineering Science Vol. 7(3), pp. 64 - 73

Ulvi A, Yakar M, Yiğit A Y \& Kaya Y (2020). İHA ve Yersel Fotogrametrik Teknikler Kullanarak Aksaray Kızll Kilise'nin 3 Boyutlu Nokta Bulutu ve Modelinin Üretilmesi. Geomatik Dergisi, 5(1), 22-30.

Yakar M \& Yılmaz H (2008). Kültürel Miraslardan Tarihi Horozluhan'ın Fotogrametrik Rölöve Çalışması Ve 3 Boyutlu Modellenmesi. Selçuk Üniversitesi Mühendislik, Bilim Ve Teknoloji Dergisi, 23 (2) , 2533.

Yakar M, Kabadayı A, Yiğit A Y, Çıkıkcı K, Kaya Y \& Catin S (2016). Emir Saltuk Kümbeti Fotogrametrik Rölöve Çalişmasi Ve 3Boyutlu Modellenmesi.

Yakar M, Orhan O, Ulvi A, Yiğit A Y \& Yüzer M M (2015). Sahip Ata Külliyesi Rölöve Örneği, TMMOB Harita ve Kadastro Mühendisleri Odası, 15. Türkiye Harita Bilimsel ve Teknik Kurultayı, 25-28 Mart 2015, Ankara

Yakar M, Yıldız F \& Yılmaz H M (2005). Tarihi Ve Kültürel Mirasların Belgelenmesinde Jeodezi Fotogrametri Mühendislerinin Rolü, TMMOB Harita ve Kadastro Mühendisleri Odası, 10. Türkiye Harita Bilimsel ve Teknik Kurultayı, 28 Mart - 1 Nisan 2005, Ankara,

Yakar M, Yılmaz H M \& Mutluoğlu Ö (2009). Hacim Hesaplamalarında Laser Tarama Ve Yersel Fotogrametrinin Kullanılması, TMMOB Harita ve Kadastro Mühendisleri Odası, 12. Türkiye Harita Bilimsel ve Teknik Kurultayı, 11 - 15 Mayıs 2009, Ankara

Yardımcı G (2019a). İnsansız Hava Aracı Kullanımından Doğan Sorumluluk, Journal of Aviation, 3 (2): 132-150, e-ISSN: 2587-1676.
Yardımcı G (2019b). İnsansız Hava Araçlarına Türk Mevzuatından Bir Bakıș, Journal of Aviation, 3 (1): 61-80, e-ISSN: 2587-1676.

Yiğit A \& Ulvi A (2020). İHA Fotogrametrisi Tekniği Kullanarak 3B Model Oluşturma: Yakutiye Medresesi Örneği. Türkiye Fotogrametri Dergisi, 2 (2), 46-54

Yiğit A Y \& Uysal M (2020). Automatic Road Detection from Orthophoto Images. Mersin Photogrammetry Journal, 2(1), 10-17.

\section{Internet Kaynakları}

\section{(URL-1)}

https://paksoyteknik.com.tr/index.php/paksoy -topcon/iha (erişim tarihi: 01.03.2021)

(URL-2)

https://www.resmigazete.gov.tr/arsiv/6029.pd f (erişim tarihi: 01.03.2021)

(URL-3)

https://www.resmigazete.gov.tr/eskiler/2018/ 07/20180715-1.pdf (erişim tarihi: 01.03.2021)

(URL-4)

https://www.mevzuat.gov.tr/MevzuatMetin/1. 5.2920.pdf (erişim tarihi: 01.03.2021)

(URL-5)

http://web.shgm.gov.tr/documents/sivilhavacil ik/files/mevzuat/sektorel/talimatlar/2020/SHTIHA_Rev-04.pdf 